\title{
Congenital Hyperinsulinism
}

National Cancer Institute

\section{Source}

National Cancer Institute. Congenital Hyperinsulinism. NCI Thesaurus. Code C131425.

An etiologically heterogenous condition resulting in dysregulated insulin secretion whose cause is present from birth. It is the most common cause of persistent hypoglycemia in neonates, infants and children. 